\title{
THE RELIABILITY ANALYSIS OF EXISTING REINFORCED CONCRETE PILES IN PERMAFROST REGIONS
}

\author{
Vladimir S. Utkin, Leonid A. Sushev \\ Vologda state university, Vologda, RUSSIA
}

\begin{abstract}
The article describes the general problem of safe operation of buildings and structures with the dynamics of permafrost in Russia and other countries. The global warming on Earth will lead to global disasters such as failures of buildings and structures. The main reason of these failures will be a reduction of bearing capacity and the reliability of foundations. It is necessary to organize the observations (monitoring) for the process of reducing the bearing capacity of foundations to prevent such accidents and reduce negative consequences, to development of preventive measures and operational methods for the piles reliability analysis. The main loadbearing elements of the foundation are reinforced concrete piles and frozen ground. Reinforced concrete piles have a tendency to decrease the bearing capacity and reliability of the upper (aerial) part and the part in the soil. The article discusses the problem of reliability analysis of existing reinforced concrete piles in upper part in permafrost regions by the reason of pile degradation in the contact zone of seasonal thawing and freezing soil. The evaluation of the probability of failure is important in itself, but also it important for the reliability of foundation: consisting of piles and frozen soil. Authors offers the methods for reliability analysis of upper part of reinforced concrete piles in the contact zone with seasonally thawed soil under different number of random variables (fuzzy variables) in the design mathematical model of a limit state by the strength criterion.
\end{abstract}

Keywords: permafrost; foundation; reinforced concrete piles; compression; theory of possibility; evidence theory; buildings; construction

\section{РАСЧЕТ НАДЕЖНОСТИ ЖЕЛЕЗОБЕТОННЫХ СВАЙ НА СТАДИИ ЭКСПЛУАТАЦИИ В УСЛОВИЯХ ВЕЧНОЙ МЕРЗЛОТЫ}

\author{
В.С. Уткин, Л.А. Сушев \\ Вологодский государственный университет, г. Вологда, РОССИЯ
}

\begin{abstract}
Аннотация. Рассматривается общая проблема безопасности эксплуатации зданий и сооружений в условиях динамики вечной мерзлоты применительно к Российской Федерации и другим странам. Глобальное потепление на Земле приведет к глобальным катастрофам в виде разрушений зданий и сооружений. Основной причиной разрушений будет снижение несущей способности и соответственно надежности оснований фундаментов. Для предупреждения таких аварий и снижения негативных последствий необходима организация наблюдений (мониторинг) за процессом снижения несущей способности оснований фундаментов, разработка предупредительных мероприятий и оперативная оценка надежности (безопасности) свайных оснований. Основными несущими элементами основания являются железобетонные сваи и мерзлый грунт. Сваи имеют тенденцию к снижению несущей способности и надежности верхней (надземной) части и части находящейся в грунте. В работе рассматривается проблема расчета надежности верхней части железобетонных свай на стадии эксплуатации зданий и сооружений в условиях вечной мерзлоты в связи с их снижением несущей способности в зоне контакта сезонного оттаивания и замерзания грунта. Оценка их вероятности безотказной работы важна сама по себе, а также необходима для определения надежности всего основания, состоящего из свай и мерзлого грунта. Рассмотрены методы для расчетов надежности верхней части железобетонной сваи в зоне контакта с сезонно оттаивающим грунтом при различном числе случайных величин (нечетких переменных) в расчетной математической модели предельного состояния по критерию прочности сваи. Полученная в результате работы информация является необходимой частью для определения надежности свайного основания зданий и сооружений.
\end{abstract}

Ключевые слова: вечная мерзлота, свайные основания, железобетонные сваи, сжатие, теория возможностей, теория свидетельств 


\section{INTRODUCTION}

The Russian State Standard GOST 31937-2011 came into force in 2010. According to this GOST, the safety of buildings and structures is characterized by a residual resource (lifetime) and technical condition category. The same requirements are specified in the International Standard ISO 2394:1998, «General principles on reliability for structures»». Measures of structural safety are risk value, reliability, residual resource (lifetime) by all limit state criteria. The assessment of technical condition category and reliability requires the development of new methods for implementation of requirements of new Russian State Standards: GOST 319372011, SP 25.13330.2012, SP 63.13330.2012, etc. The special difficulty in realization of these requirements shows up when it applies to building in the conditions of the permafrost, which occupied more than 60 percent of territory of The Russian Federation, large area of Canada and some other countries. The significance of the problem for global warming (RIA News «Round table») was declared by the MES Deputy Minister of Russian Federation - R. Tsalikov, who noted that "more than a quarter of the housing stock may be subjected to failures", and "with increasing mean annual temperature by 1 2 degrees bearing capacity of piles in the permafrost regions will be reduced by 50 percent" [1]. The article [2] presents the results of testing the hanging precast piles for their bearing capacity depending on the temperature of the soil. Temperature increasing from -10 to $-0.3 \mathrm{C}$ reduces its bearing capacity of the middle-sized sand by almost nine times, and almost seven times for clay soils. The article [3] presents the dynamics of the modern climate of the North and the Northern territories with permafrost. The article [3] also notes that a moistening of the seasonally thawing layer of soil (sharply increased in recent) and the thawing of the upper horizons of permafrost has a great impact on the engineering structures. As a result, about 300 buildings in Norilsk (Russian Federation) had to be dismantled due to the reduction of their reliability.
The number of structures with deformations from the differential settlement of frozen soils is increased by $42 \%$ in Norilsk (in 61\% Yakutia) in 1990-1999. All this is due to the climate change and to the poor performance of inspection services [3]. The problems of reliability analysis of structures in the permafrost regions were considered in the foreign papers [3-8].

In the conditions of permafrost and global warming, which currently observed on the territory of the Russian Federation, the greatest relevance is an ensuring of the safe operation of buildings and structures are their foundations. As a result of warming, the bearing capacity of foundations is reducing [9]. Most of the structures in permafrost regions have pile foundations. Accordingly, the main problem in the area of structures safety management now is developing methods for technical condition assessment and the periodic reliability analysis of the pile foundations. Quantitative measure of the technical condition of foundations and piles is their bearing capacity, which is characterized by the ultimate load which does not lead the foundation or individual piles to the limit state. The measure of the reliability of pile foundation is the probability of non-failure. It should be noted that one part of the pile is in the frozen ground, and the other part of it is in the layer of seasonal thawing soil and in the air to the pile cap.

\section{PROBLEM STATEMENT}

The pile foundation includes piles, the largest part of its length is in the surrounding soil. Accordingly, the bearing capacity of the pile foundation depends on bearing capacity of piles and the soil. In the contact of the upper part of piles with the surface of soil in the co nditions of the seasonal thawing there is a degradation of materials in reinforce concrete piles. It leads to the reduction of the bearing capacity of the piles and their reliability [10]. In terms of the reliability theory, the construction of pile foundation is represented as a sequential system consisting of two elements: the piles at the level 
of seasonal thawing with access to the pile cap and the permafrost soil with the piles. The reliability (probability of non-failure) of the sequential system in probabilistic-statistical methods of reliability analysis is calculated as the multiplication of the probabilities: $P=P_{1} \cdot P_{2}$, where $P_{1}$ - the probability of non-failure of the piles at the level of seasonal thawing and higher; $P_{2}-$ the probability of non-failure of the permafrost soil with the piles (i.e. $P=P_{1} \cdot P_{2}$ ). The most dangerous time of year for such foundations is the summer, when reducing of bearing capacity (as a result of thawing of the upper soil layer and as a result of weakening of the pile from degradation of pile materials by periodic freezing and thawing of soil around the piles results in lower level of safety of the foundations and structures in general. In this regard, the reliability analysis of the RC piles and the soil with the piles is an important and actual problem currently. The present article describes the problem of the reliability analysis of only the upper part of the pile.

\section{LITERATURE REVIEW}

In State Standard GOST 27751-2014 "Reliability of structures and foundation soils" it is noted that probabilistic-statistical methods is applicable for reliability analysis "even there sufficient data about the parameters variability are available" in a design model. Academician V. V. Bolotin [11] also points to the necessity for "finding the distribution functions and other probabilistic characteristics of random variables" in the reliability analysis, which requires a "full" statistical information about the parameters in the design model. Using of continuous uniform distribution for extremely small information to describing random variables, in which the two values of a random variable it is already possible to find an unambiguous value of probability of an event, in the task of evaluating the level of safety and for other important tasks cannot be recommended because of the low accuracy of the results.

The calculation of the upper part of the pile according to the criterion of the bearing capacity (strength criterion) overlaps with the calculation of short reinforced-concrete columns. The paper [12] contains the results of research and reliability analysis of reinforced-concrete columns, but with full statistical information using probabilistic methods. The reliability analysis of reinforced-concrete columns was conducted in the article [12] with limited information, using distribution functions based on Chebyshev inequality. The reliability analysis of reinforced concrete columns was conducted in the paper [13] with limited information, using interval truncated distribution function. However, these distributions require more detailed information about the monitored parameters, in particular, the knowledge of the expected value and standard deviation, and the extreme values of the sample. In addition, all the above works do not consider the equality of strain of concrete and reinforcement in reinforced-concrete columns in the design mathematical model of limit state in the column when it is compressed.

\section{RELIABILITY ANALYSIS}

The article describes a new method for the reliability analysis $\left(P_{1}\right)$ of the existing RC pile part, located in the upper active layer of the soil. The proposed method of reliability analysis is addition to existing methods for reliability analysis, which based on probabilistic and statistical methods with full statistical information about the random variables in the design mathematical models of limit states (recommended by GOST 27751-2014). The solution to this problem will allow using it in reliability analysis of reinforced-concrete piles in all conditions of their work, i.e. outside the permafrost regions, and also determining the risk (measure of danger), which expands the relevance of the article. It is known [15] that the bearing capacity of compressed concrete piles above the surface of the 
frozen soil on the strength criterion is defined (without taking into account the various factors) by the formula [15]:

$$
N_{\text {pile }}=R_{b} A_{b}+R_{s} A_{s},
$$

where $R_{b}$ - the design compressive strength (resistance) of the concrete piles, which defined at the stage of operation by non-destructive test; taking into account the limited number of these tests for singe RC pile, it is advisable to use instead the $R_{b}$ average compressive strength $\bar{\sigma}_{b}$ obtained by 3-5 non-destructive tests. So, we use average compressive strength $\bar{\sigma}_{b}$ in (1) instead $R_{b} ; R_{s}$ - the design strength (resistance)of steel reinforcement, which is taken by the standards depending on the type of rebar; $A_{b}$ and $A_{s}$ - cross-section area of concrete and steel reinforced in pile.

In areas close to the pile cap could be used the formula (1). But, taking into account the strain equality of concrete $\varepsilon_{b}$ and reinforcement $\varepsilon_{s}$ in pile and a significant (about 10 times) the difference of the modules of elasticity of concrete and steel, and the ability to deform steel and after reaching the yield strength(which is not allowed by $R_{S}$ value), the calculation of the pile bearing capacity $N_{c b}$ according to the strength criterion in compression should be based on a formula, which takes into account equality of strains of concrete and reinforcement $\varepsilon_{b}=\varepsilon_{s}$ according to the formula:

$$
\bar{N}_{\text {pile }}=\bar{\sigma}_{b} A_{b}+\bar{\varepsilon}_{b} E_{s} A_{s},
$$

where $E_{S}$ - modules of elasticity of steel reinforcement accepted as the determined value because his small variability [15]: $E_{S}=2 \cdot 10^{5}$ $\mathrm{MPa} ; \sigma_{b}$ - concrete compression strength, which is calculated by the value of strain in concrete piles in compression $\varepsilon_{b}$ and modules of elasticity of concrete $E_{b}$ as: $\sigma_{b}=\varepsilon_{b} E_{b}$.
Based on all remarks, the bearing capacity of $\mathrm{RC}$ pile on (2) is possible to present as:

$$
\bar{N}_{\text {pile }}=\bar{\varepsilon}_{b}\left(E_{b} A_{b}+E_{s} A_{s}\right) .
$$

Accepted in Russian State Standards (SP and SNiP) limit strain of rebar by the possibility of losing rebar stability with the formation of longitudinal cracks in concrete does not prove to be correct in this case because of the short part of pile between soil and pile cap for structures in the permafrost regions.

Thus, the problem is taken to determining the value of existing load $\tilde{N}_{e x}$, when determin$\operatorname{ing} \widetilde{N}_{e x}$ by collecting loads it is impossible to determine the stress on concrete pile. Moreover, it is difficult to determine the most damaged or the most loaded pile taking into account uneven distribution of the loads on piles.

It is therefore proposed to determine the bearing capacity of piles by experiment, in all conditions and in permafrost regions only in summer time. The most loaded or most damaged pile (as a rule, being in the corner of structure at the same amount of floors or on an area with the large number of floors) are selected for tests. Then resistance strain gauges are glued at different height in a reinforced-concrete pile above the ground surface and above the degraded pile site on four of its surfaces (for piles of square section) and measure their ohmic resistances $R_{0}$. Then milled flat layer of concrete (with no rebar) above and below the gages to the depth, at which the imperceptible change in the resistance of gauges, and re-defined their ohmic resistance as $R_{1}$. The engineering strain can be calculated as:

$$
\varepsilon=\frac{\left|R_{0}-R_{1}\right|}{R_{0} k},
$$

where $\mathrm{k}$ - the factor of the strain gauge sensitivity. The engineering strain of the concrete is calculated at the all faces of the pile. Then it is calculated the average value 


$$
\bar{\varepsilon}=0.25\left(\varepsilon_{1}+\varepsilon_{2}+\varepsilon_{3}+\varepsilon_{4}\right) .
$$

Statistical analysis of the results of ohmic resistances $R_{i}(i=1,2,3,4)$ or strains $\varepsilon_{i}$ measurements is carried out by probabilistic methods. However, the results of reliability analysis by probabilistic methods may not be correct with such a small size of statistical information about $\varepsilon_{i}$ of one pile. In this regard, it is proposed to carry out the reliability analysis of piles based on the theory of possibilities [17-22] with a small amount of experimentally acquired data about the test parameters (random variables). Random variable or fuzzy variable (in terms of possibility theory [17-22]) is described by a distribution function of possibilities $\pi_{\widetilde{N}}(N)$ or (in general) $\pi_{X}(x)$. The greatest using has received a fuzzy function [17-22]:

$$
\pi_{X}(x)=\exp \left[-\left(\frac{x-a_{x}}{b_{x}}\right)^{2}\right],
$$

where

$$
a_{x}=0,5 \cdot\left(X_{\max }+X_{\min }\right) ; b_{x}=\frac{\left(X_{\max }-X_{\min }\right)}{2 \sqrt{-\ln \alpha}},
$$

$X_{\max }$ and $X_{\min }$ - the maximum and minimum value of fuzzy variable $X ; \alpha \in[0 ; 1]$ - the cutoff level, which value are set [20].

Figure 1 shows the form of this function (5) with its parameters.

More information about the fuzzy functions can be found in the articles [17-22].

If a condition

$$
a_{x} \leq \varepsilon_{b}\left(E_{b} A_{b}+E_{s} A_{s}\right)
$$

is executed, then the pile possibility of nonfailure $R$ according to the criterion (4) it is deemed to be equal to one. For existing buildings and structures, this condition usually performed.

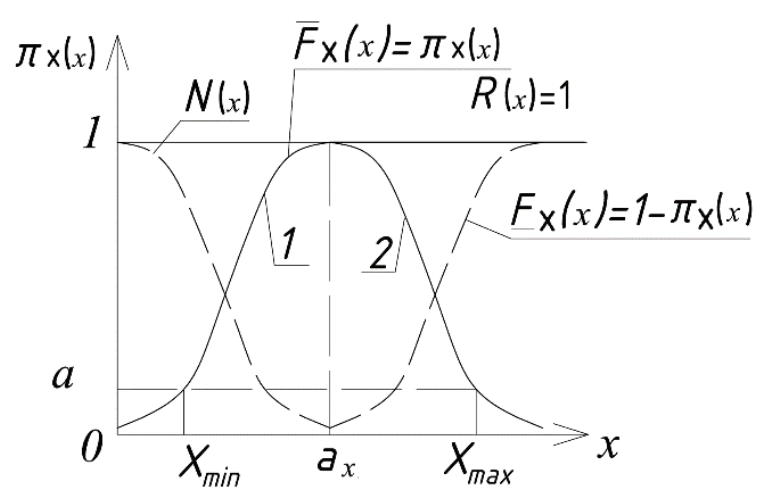

Figure 1. Fuzzy function $\pi_{X}(x) \cdot \underline{F}(x), \bar{F}(x)-$ the lower and upper (boundary) distribution function of the fuzzy variable X. 1 - the left branch, 2 - the right branch.

The possibility of failure $Q$ in this case is equal to

$$
\pi_{X}(x)=\exp \left[-\left(\frac{\varepsilon_{b}\left(E_{b} A_{b}+E_{s} A_{s}\right)-a_{x}}{b_{x}}\right)^{2}\right] .
$$

The necessity of non-failure is calculated as $N=1-Q$. The value of reliability of the piles according to the criterion (4) will be characterized by the interval $[N ; R]$. It can be represented in probabilistic terms as $[\underline{P} ; \bar{P}]$, where $\underline{P}$ and $\bar{P}-$ the lower and upper values of probability of non-failure.

In responsible cases, it is impossible to use reliability analysis for the one pile. Then the described method of reliability analysis is used for several piles. As a result, we have a set of values of the reliability intervals $\left[\underline{P}_{i} ; \bar{P}_{i}\right], i=1 \ldots n$. It is possible to find the statistical expected value of reliability on the evidence theory [22-25] as an interval $[\underline{P} ; \bar{P}]$, where

$$
\underline{P}=\underline{\mathrm{E}} X=\sum_{i=1}^{n} m\left(A_{i}\right) \inf A_{i}
$$

and 


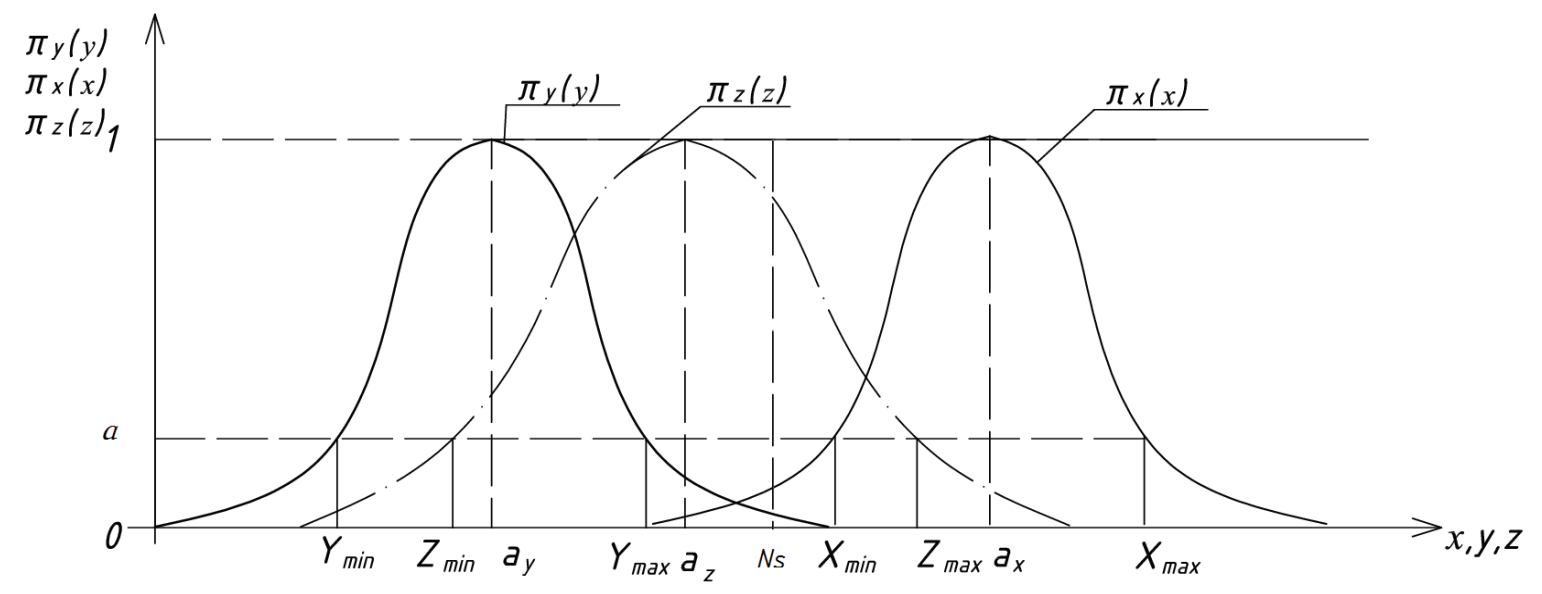

Figure 2. Illustration of the subtraction of fuzzy variables $\pi_{X}(x)-\pi_{Y}(y)=\pi_{Z}(z)$

$$
\bar{P}=\overline{\mathrm{E}} X=\sum_{i=1}^{n} m\left(A_{i}\right) \sup A_{i} .
$$

\section{Example 1. Let following} values are conditionally known: $E_{S}=2 \cdot 10^{11} \mathrm{~Pa}$; $E_{b}=2 \cdot 10^{9} \quad \mathrm{~Pa} ; \quad A_{b}=0.3 \cdot 0.3=0.09 \mathrm{M}^{2}$; $A_{s}=3 \cdot 10^{-4}$ $\mathrm{m}^{2}$ $N_{\text {ult }}=\varepsilon_{\text {ult }}\left(E_{b} A_{b}+E_{s} A_{s}\right)=10.46 \cdot 10^{6} \quad \mathrm{~N}$. We will set the value of load on a pile by results the pile tests in a form: $\widetilde{N}_{e x}=\{8,9,10,11\} \cdot 10^{6} \mathrm{~N}$; $a_{x}=9.5 \cdot 10^{6}$ $\mathrm{N}$;

$b_{x}=(11-8) / 2 \sqrt{\ln 0.01}=0.7 \cdot 10^{6} \quad \mathrm{~N} \quad$ with $\alpha=0,01$. As $a_{x}=9.5 \cdot 10^{6}<10.46 \cdot 10^{6} \mathrm{~N}$, then $R=1$.

$Q=\exp \left\{-\left[\frac{10.46-9.5}{0.7}\right]^{2}\right\}=\exp (-1.88)=0.15$. Then necessity of non-failure is $N=1-Q=1$ $0,15=0,85$. The reliability interval is $[0.85 ; 1]$.

If the modulus of elasticity of concrete $E_{b}$ is evaluated by nondestructive testing too, then a fuzzy variable $\widetilde{E}_{b}$ is described by the function (5). A mathematical model of the limit state (5) takes the form:

$$
\tilde{N}_{e x} \leq \varepsilon_{u l t}\left(\widetilde{E}_{b} A_{b}+E_{s} A_{s}\right) .
$$

Multiplication of fuzzy variable by deterministic value - is a fuzzy variable. We'll denote $Y=\varepsilon_{u l t} \widetilde{E}_{b} A_{b}$. The $Y$ will be described by the fuzzy distribution function

We will transform expression (6) as:

$$
X-Y \leq \varepsilon_{u l t} E_{s} A_{s}
$$

where the right part of inequality is deterministic value.

Figure 2 shows the function of fuzzy variable $Z=X-Y$ obtained by subtracting the functions $\pi_{X}(x)-\pi_{Y}(y)$ [26] with $a_{X}>a_{Y}$.

As a result we have $Z_{\text {min }}=X_{\text {min }}-Y_{\max }$ and $Z_{\max }=X_{\max }-Y_{\min }$. The uncertainty of information about the fuzzy variable $Z$ increases in comparing with $\mathrm{X}$ and $\mathrm{Y}$. At the same time $a_{z}=a_{x}-a_{y}$. If $a_{z} \leq N_{s}=\varepsilon_{u l t} E_{s} A_{s}$, then $\mathrm{R}=1$ (as conventionally shown in Fig. 2 with $\varepsilon_{u l t} E_{s} A_{s}=N_{s}$ for compactness). The possibility of failure $Q$ calculated as $Q=\pi_{z}\left(z=N_{s}\right)$, or in the wide form

$$
Q=\exp \left[-\left(\frac{N_{s}-a_{z}}{b_{z}}\right)^{2}\right]
$$

where $b_{z}=b_{x}+b_{y}$. 
The necessity of non-failure is calculated as $N=1-Q$. The reliability will be characterized by the interval $[N ; R]$.

Example 2. Let following ues are conditionally

val$N_{u l t}=\varepsilon_{u l t} E_{S} A_{S}=4.2 \cdot 10^{-3} \cdot 2 \cdot 10^{11} \cdot 0.03=25.2 \cdot 10^{3}$ $\mathrm{kN} ; \quad a_{x}=30 \cdot 10^{3} \mathrm{kN} ; \quad a_{y}=11.34 \cdot 10^{3} \mathrm{kN}$; $b_{x}=3 \cdot 10^{3} \mathrm{kN} ; \quad b_{y}=1 \cdot 10^{3} \mathrm{kN}$. Then $a_{z}=30 \cdot 10^{3}-11.34 \cdot 10^{3}=18.66 \cdot 10^{3} \mathrm{kN}$ $\leq N_{s}=25.2 \cdot 10^{3} \mathrm{kN}$ and possibility of nonfailure $R=1 . b_{z}=b_{x}+b_{y}=4 \cdot 10^{3} \mathrm{kN}$. The possibility of failure is $Q=\exp \left[-\left(\frac{N_{u l t}-a_{z}}{b_{z}}\right)^{2}\right]=\exp \left[-\left(\frac{25.2 \cdot 10^{3}-18.66 \cdot 10^{3}}{4 \cdot 10^{3}}\right)^{2}\right]=0.069$. The necessity of non-failure is $N=1$ $0,069=0,931$. The reliability will be characterized by the interval $[0.931 ; 1]$.

A more realistic assessment of the reliability of piles can be obtained from a wider set of test piles of the same structure. In this case, we will have a subset of intervals of reliability. For their statistical analysis uses of evidence.[22-25], as noted above.

Let's consider the evaluation of the statistical expected value of reliability on information as subset of the intervals of reliability. Let following values of reliability intervals are conditionally known $[0,91 ; 1] ;[0,92$; $1] ;[0,93 ; 1] ;[0,93 ; 1] ;[0,90 ; 1]$. By condition of example: $C_{i}=1, N=5$. For the data given in intervals, we will have

$$
m\left(A_{1}\right)=\frac{1}{5} ; m\left(A_{2}\right)=\frac{1}{5} ; m\left(A_{3}\right)=\frac{1}{5} ; m\left(A_{4}\right)=\frac{1}{5} ; m\left(A_{5}\right)=\frac{1}{5} .
$$

So

$$
\overline{\mathrm{E}} X=\frac{(1+1+1+1+1)}{5}=1
$$

and

$$
\underline{E} X=\frac{(0.92+0.91+2 \cdot 0.93+0.90)}{5}=0.918 \text {. }
$$

The statistical expectation value of reliability will be presented in the form of interval [0.918;1].

\section{CONCLUSIONS}

1. The problem of influence of global warming on Earth is considered for the reduction in the reliability (safety) of piles in permafrost regions as a result of reduction of the bearing capacity of reinforced concrete piles from the degradation of the concrete.

2. The methodology of reliability analysis of reinforced-concrete piles is first represented according to the strength criterion with limited statistical information on controlled parameters, with refinement of existing design formulas for RC piles in compression;

3. Two cases are considered for the reliability analysis of reinforced-concrete piles with different number of fuzzy variables in the mathematical design models of limit state;

4. Examples of reliability analysis of RC piles are given as an algorithm for calculations;

5. Possibility of account of reliability analysis of a few piles is first shown with the use of evidence.

\section{REFERENCES}

1. Priroda Rossii. Natsionalnyy portal. [Russian nature. National portal] [online]. URL: www.priroda.ru/item/387 (accessed: 30.12.2015).

2. Semelit V.Yu., Gruzin A.V. Vliyanie temperatury grunta na nesushchuyu sposobnost svai v usloviyakh vechnoy merzloty [Effect of soil temperature on the bearing capacity of the pile in the permafrost]. Problemy geologii i osvoeniya nedr, 2013, No. 2, pp. 422-423. 


\section{Vasilev A.A., Drozdov D.S., Moskalenko} N.G. Dinamika temperatury mnogoletnmerzlykh porod Zapadnoy Sibiri v svyazi s izmeneniyami klimata [Dynamics of permafrost temperatures in Western Siberia breeds in relation to climate change]. Kriosfera zemli, 2008, Vol. XII, No. 2, pp. 10-18.

4. ACIA 2004. Impacts of warming arctic: climate impact assessment. Cambridge, Cambridge Univ. Press, 2004, 228 p.

5. ACIA 2005. Arctic climate impact assessment. Cambridge, Cambridge Univ. Press, 2005, 234 p.

6. Pavlov A.V., Malkova G.V. Sovremennye izmeneniya klimata na severe Rossii. Albom melkomasshtabnykh kart [Modern climate change in northern Russia. Album of small-scale maps]. Novosibirsk, Geo, 2005, $54 \mathrm{p}$.

7. Romanovsky V.E., Smith S.L., Christiansen H.H. Permafrost thermal state in the polar Northern Hemisphere during the international polar year 2007-2009: a synthesis. Permafrost and Periglacial Processes, 2010, Vol. 21, pp. 106-116.

8. Oberman N.T., Shesler I.G. Sovremennye i prognoziruemye izmeneniya merzlotnykh usloviy evropeyskogo severo-vostoka Rossiyskoy Federatsii [Current and projected changes in permafrost conditions for European Russia northeast]. Problemy Severa i Arktiki Rossiyskoy Federatsii: Nauchnoinform. Byul, 2009. Vol. 9, pp. 96-106.

9. Kluzek E.B., Olson J., Rosinski J. User's guide to NCAR CCM 3.6. Boulder. Colorado, USA, 1996, $147 \mathrm{p}$.

10. Khrustalev L.N., Davydova I.V. Prognoz potepleniya klimata i ego uchet pri otsenke nadezhnosti osnovaniy zdaniy na vechnomerzlykh gruntakh [Forecast of global warming and its account in assessing the reliability of the bases of buildings on permafrost]. Kriosfera Zemli, 2007, Vol. XI, No. 2, pp. 68-75.

11. Bolotin V.V. Prognozirovanie resursa mashin i konstruktsiy [Forecasting of re- source of machines and constructions]. Moscow, Mashinostroenie, 1984, 312 p.

12. Sorokin Ye.V. Raschet i prognozirovanie dolgovechnosti zhelezobetonnykh konstruktsiy [Calculation and prediction of durability of reinforced concrete structures]. Ph.D. thesis. Penza, 2014, 179 p.

13. Yarygina O.V. Metody rascheta nadezhnosti zhelezobetonnykh konstruktsiy v sostave zdaniy i sooruzheniy pri ogranichennoy statisticheskoy informatsii [Reliability Analysis of Reinforced Concrete Structures of Buildings and Facilities in Conditions of Limited Statistical Information]. Ph.D. theses. Saint-Petersburg, 2013, 23 p.

14. Utkin V.S., Yarygina O.V. Raschet nadezhnosti zhelezobetonnoy kolonny po kriteriyu prochnosti na stadii ekspluatatsii [Calculation of reinforced concrete columns reliability on the criterion of strength during the operational phase]. Beton i zhelezobeton, 2012, No. 4, pp. 14-16.

15. Metelyuk N.S., Shishko G.F., Soloveva A.B. etc. Svai i svaynye fundamenty. Spravochnoe posobie [Piles and pile foundations. Reference manual]. Kiev, Budivelnik, 1977, $256 \mathrm{p}$.

16. Augusti G., Baratta A., Kashiati F. Veroyatnostnye modeli $\mathrm{v}$ stroitelnom proektirovanii [Probabilistic models in building design]. Moscow, Stroyizdat, 1988, 584 p.

17. Dyubua D., Prad A. Teoriya vozmozhnostey. Prilozheniya k predstavleniyu znaniy $\mathrm{v}$ informatike [Theory of possibility. Applications to knowledge representation in computer science]. Moscow, Radio i svyaz, 1990, 288 p.

18. Utkin V.S. Safety analysis of soil beds of foundations based on bearing capacity criterion. Soil Mechanics and Foundation Engineering, 2014, Vol. 51, No. 1, pp. 9-16.

19. Utkin V.S., Solovyev S.A. Raschet nadezhnosti zhelezobetonnoy balki na stadii ekspluatatsii po kriteriyu dliny treshchiny $\mathrm{v}$ betone [Calculation of reinforced concrete beams reliability at the operation stage by 
the criterion of length of the crack in concrete]. Vestnik MGSU, 2016, No. 1, pp. 6879.

20. Utkin V.S., Solovyev S.A., Kaberova A.A. Znachenie urovnya sreza (riska) pri raschete nadezhnosti nesushchikh elementov vozmozhnostnym metodom [The value of the slice level (risk) in calculating the reliability of bearing elements possibilistic method]. Stroitelnaya mekhanika i raschet sooruzheniy, 2015, No. 6, pp. 63-67.

21. Eryilmaz S., Yazgi Tutuncu G. Stress strength reliability in the presence of fuzziness. Journal of computational and applied mathematics, 2015, Vol. 282, pp. 262-267.

22. Utkin L.V. Analiz riska i prinyatie resheniy pri nepolnoy informatsii [Risk analysis and decision making with incomplete information]. Saint-Petersburg, Nauka, 2007, $404 \mathrm{p}$.

23. Dempster A.P. Upper and lower probabilities induced by a multivalved mapping. Annals of Mathematical Statistics, 1967, Vol. 38, pp. 325-339.

24. Shafer G.A. Mathematical Theory of Evidence. Princeton University Press, 1976, $297 \mathrm{p}$.

25. Zhang Z., Jiang C., Han X., Dean Hu, Yu S. A response surface approach for Structure reliability analysis using evidence theory. Advanced in Engineering Software, 2014, pp. 37-45.

26. Utkin V.S., Utkin L.V. Opredelenie nadezhnosti stroitelnykh konstruktsiy: Uchebnoe posobie [Calculation of reliability of building structures: Textbook]. Vologda, VoGTU, 2000, 168 p.

Vladimir S. Utkin, Dr. Sc., Professor, Department of Industrial and Civil Engineering, Vologda State University; 15, Lenin Street, Vologda, 160000, Russia; Phone/fax: +7 (8172) 5183 96, e-mail: utkinvogtu@mail.ru

Leonid A. Sushev, Ph.D. Student, Department of Industrial and Civil Engineering, Vologda State University; 15, Lenin Street, Vologda, 160000, Russia; Phone/fax: +7 (8172) 51-83-96; e-mail: sushevleo@mail.ru
Уткин Владимир Сергеевич, доктор технических наук, профессор кафедры промышленного и гражданского строительства Вологодского государственного университета; 160000, Россия, г. Вологда, ул. Ленина, д. 15; тел. +7 (8172) 51-83-96,

e-mail: utkinvogtu@mail.ru

Сушев Леонид Андреевич, аспирант кафедры промышленного и гражданского строительства Вологодского государственного университета; 160000, Россия, г. Вологда, Набережная 6 Армии, д. 201, тел. +7 (8172) 27-32-82; e-mail: : sushevleo@mail.ru 